\title{
THE EFFECTIVENESS OF USING CHUNKING STRATEGY TO IMPROVE STUDENTS' READING COMPREHENSION AT THE SECOND YEAR OF SMP NEGERI 2 BAROMBONG
}

\author{
Rini Anggraeni \\ English Education Department of UIN Alauddin Makassar \\ Rini24anggraeni@gmail.com
}

\begin{abstract}
The objective of this research was to know whether chunking strategy effective to improve students' reading comprehension of the second year of SMP Negeri 2 Barombong and found the students' attitude in learning using chunking strategy. The research design applied non-equivalent control group design which is one of the forms of quasi experimental design consisting of two groups (Experimental group and controlled group) each group covering 6 meetings. This research focused on improving the students' reading comprehension in comprehending narrative text. The instruments used were reading text, observation sheet, and questionnaire.Further, the data analysis techniqueused in this research was statisticalanalysis. The findings of this research showed that chunking strategy effective to improve the students reading comprehension in which the mean score of students' post-test of experimental group was 56. It was higher than the controlled group that was only got 23.This research was successful to solve the students' problem in comprehending thetextby using chunking strategy.
\end{abstract}

KEY WORDS: Chunking Strategy, Reading Comprehension, Improve

\section{A. INTRODUCTION}

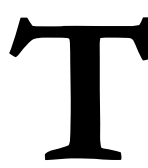

eaching reading skill to the students is very difficult thing. Its difficulties might come from the teachers who did not creative to simulate in teaching reading, lack of knowledge in teaching grammar, and the teachers did not give attention to the students needed. Other difficulties came up from the students who did not interest to read a long passage, lack of vocabulary, and understanding the meaning of what they have read.

Based on the result observation, the researcher found some problems in teaching process. They were lack of vocabulary and knowledge in reading and they do not know the function of reading whereas by reading they can get the information and knowledge. 
Rini Anggraeni, The Effectiveness of Using Chunking Strategy To Improve Students' ...

Due to of the previous problems, the researcher purpose one strategy of teaching reading to solve that problems called "Chunking Strategy" whether this strategy can improve the students' reading comprehension and make the students interest in learning process.

Furthermore, the research problem of this research was "What is the students' reading comprehension of the second year of SMP Negeri 2 Barombong by using chunking strategy?”

\section{B. LITERATURE REVIEW}

A number of studies had been conducted in order to investigate the improvement of students' reading comprehension. One of them is Mirawati (2011) in her research "Using Context Clues to Improve the Students' Reading Comprehension" stated that using context clues in learning reading can improve the students' reading comprehension. She found that the means score of students' posttest score(6.82) was higher than the students' pre-test score(3.84).Context Clues is one of the parts of chunking strategies. These clues can help readers expand vocabulary and grasp the meaning of the word, sentence, or passage.

Furthermore,Casteel theory states that the presentation of chunked material separated into meaningful related groups of words improve the comprehension of some readers, most noticeably those readers who are classified as poor or low ability reader.

It can be concluded that chunking strategy effective to improve the students' reading comprehension. Therefore, the researcher chose it as the strategy to solve the students' problem in comprehending the passage about narrative text at the second year students of SMP Negeri 2 Barombong.

\section{Chunking Strategy}

Chunkingrefers to the strategy of breaking down information into bite-sized pieces so the brain can more easily digest new information. The reason the brain needs this assistance is because working memory, which is where we manipulate information, holds a limited amount of information at one time (Malamed, 2012).

According to Malamed (2012), the procedure of chunking strategy to apply in teaching reading comprehension consists of five steps. Those steps are as follows:

\section{a. Step one: Preparation}

Chunking can be used with challenging texts of any length. A paragraph can be chunked into phrases and sentences while a reading of several pages can be 
chunked into paragraphs or sections. It is often helpful to have students' record information about each "chunk" in a graphic organizer, which you may want to prepare in advance.

\section{b. Step two: Review reading strategies}

Before having students work on paraphrasing the text, it is helpful to go over specific decoding strategies. You may want to post the following "reading reminders" on the board:

1) Circle words that are unfamiliar.

2) Use context clues to help define.

3) Look up the meaning of unknown words.

4) Write synonyms for these new words in the text.

5) Underline important places and people and identify.

6) Read aloud.

7) Read multiple times.

\section{c. Step three: Chunk the text}

"Chunking the text" simply means breaking the text down into smaller parts. Sometimes teachers chunk the text in advance for students, especially if this is the first time students have used this strategy. Other times, teachers ask students to chunk the text. Students can work on chunking texts with partners or on their own. Depending on students' reading level, the lengths of chunks can vary. A struggling reader may work with phrases, rather than sentences. A stronger reader can often work with longer chunks.

\section{Example:}

When a student reads a large piece of text, he should separate chunks where it makes sense to break up the story before rewriting it under subheadings or numbers. For instance, when reading the story of Cinderella, students break up the text into subheadings such as "Cleaning House," "The Evil Stepsisters," "The Evil Stepmother,"'"Someday My Prince Will Come," "The Lost Shoe" and "Happily Ever After." This activity gives students tools to break up longer passages and read smaller, more manageable pieces for better understanding (Lauren, 2012).

\section{d. Step four: Paraphrase meaning}

Students should rewrite "chunks" in their own words. By the end of this activity, students should have a paraphrased version of the original text. 
Rini Anggraeni, The Effectiveness of Using Chunking Strategy To Improve Students' ...

\section{e. Step five: Assessment and sharing}

The paraphrased text can be used to evaluate students' understanding and reading ability. You can also have students compare their versions of the text. This step often leads to interesting discussion about interpretation - how people can often find different meaning in the same words.

\section{RESEARCH METHOD}

This research was about the Nonequivalent Control Group Design which is one of the forms of quasi experimental group design. This research consisted of two groups (experimental and controlled group). Both of groups were given pre-test and post-test for finding out whether or not chunking strategy can improve the students' reading comprehension. This research was conducted at the second year of SMP Negeri 2 Barombong. The research procedures of this study were giving the pre-test, implementing the treatment, and conducting the post-test. The procedures of collecting data as follows:

\section{PROCEDURE OF COLLECTING DATA}

In collecting data, there were three steps that the researcher did. The first was giving the pre-test to the students, implementing the treatment, and the last was conducting the post-test. The explanation of each step was given below:

\section{Pre-test}

Before implementing the treatment, firstly the researcher conducted a pretest both of control and experimental group on $23^{\text {th }}$ February 2015 to finding out the basic score of students' reading comprehension. The test consisted of 20 numbers of multiple choices and the students' were given 40 minutes to answer all the questions that the researcher provided in the paper sheet. At the first time, the researcher held self-introduction and explained the aim of her research to the students. Then, the researcher gave them pre-test.

\section{Treatment}

The researcher gave treatment to experimental group for six meetings. From, $18^{\text {th }}$ February 2015 up to $9^{\text {th }}$ March 2015. The experimental group was taught by using Chunking Strategy while the control group was taught by their teacher without using Chunking Strategy (It means other strategy). 
Below would be presented the steps of treatment that the researcher conducted each meeting:

\section{a. First Meeting}

The first treatment was conducted on February $18^{\text {th }} 2015$.

1) The researcher introduced herself to the students and explained her goal to conduct the research and what should the students do during the research.

2) The researcher explained about narrative text.

3) The researcher explained chunking strategy and how to chunk the narrative text.

4) The researcher gave the passage about narrative text "A Greedy DogStory" The researcher and asked the students to chunk it. The strategies were:
a) Circle the words that were unfamiliar.
b) Used context clues to help define.
c) Looked up the meaning of unknown words.
d) Wrote synonyms for these new words in the text.
e) Underlined important places and people and identify.
f) Read aloud.
g) Read multiple times.

\section{b. Second Meeting}

The second treatment was conducted on February $23^{\text {th }} 2015$

1) The researcher prepared narrative text about "The Missing Dog."

2) The researcher asked the students to chunk the text. The strategy were:

a) Circle the words that were unfamiliar.

b) Used context clues to help define.

c) Looked up the meaning of unknown words.

d) Wrote synonyms for these new words in the text.

e) Underlined important places and people and identify.

f) Read aloud.

g) Read multiple times.

3) The students were asked to answer the question that was provided in the paper.

4) The researcher asked the students to share their understanding version about the text and the researcher gave score.

\section{c. Third Meeting}

The third treatment was conducted on February $25^{\text {th }} 2015$. 
Rini Anggraeni, The Effectiveness of Using Chunking Strategy To Improve Students' ...

1) The researcher prepared narrative text about "The Proud Lion" The researcher asked the students to chunk the text based on their version.

2) The students were asked to answer the question that was provided in the paper.

3) The researcher asked the students to share their understanding version about the text and the researcher gave score.

\section{d. Fourth Meeting}

The fourth treatment was implemented on March $2^{\text {nd }} 2015$

1) The researcher prepared narrative text about "The Story of the Smart Parrot"

2) The researcher asked the students to chunk the text based on their version.

3) The students were asked to answer the question that was provided in the paper.

4) The researcher asked the students to share their understanding version about the text and the researcher gave score.

\section{e. Fifth Meeting}

The fifth treatment was implemented on March $4^{\text {th }} 2015$

1) The researcher prepared narrative text about "The Four Little Rabbits."

2) The researcher asked the students to chunk the text based on their version.

3) The students were asked to answer the question that was provided in the paper.

4) The researcher asked the students to share their understanding version about the text and the researcher gave score.

\section{f. Sixth Meeting}

The fourth treatment was implemented on March $9^{\text {th }} 2015$

1) The researcher prepared narrative text about "The Old Man and the Durian Tree"

2) The researcher asked the students to chunk the text based on their version.

3) The students were asked to answer the question that was provided in the paper.

4) The researcher asked the students to share their understanding version about the text and the researcher gave score.

\section{Post-test}

After implementing the treatment, the researcher conducted the post-test both of the control and experimental group on March $11^{\text {st }} 2015$. It was done to collected the data for finding out and measure whether there is an improvement of students' score of reading comprehension or not. The reading test consisted of 20 
numbers of multiple choice and the students were given 40 minutes to answer all the questions that was provided in the paper sheet.

\section{E. FINDINGS AND DISCUSSION}

\section{Findings}

The findings of the research obtain the result percentage of the students' score of pre-test and post-test, the mean score and standard deviation of students' pre-test and post-test, the test of significant, the students' attitude, and the test correlation between students' achievement and students' attitude.

\section{a. The classification of students' pre-test and post-test score in experimental and control group}

Before giving the treatment, the researcher conducted pre-test both of experimental and control group. The result of pre-test was acquired to know the students' degree in mastering the reading text. After giving pre-test, the students' score was calculated and was classified based on the scale in p.44. All the students' score of pre-test both of experimental and control group can be seen in the following table:

Table 4.1 The Data Percentage of Students' Score of Pre-test

\begin{tabular}{|c|l|c|c|c|c|c|}
\hline \multirow{2}{*}{ No } & Classification & \multirow{2}{*}{ Score } & \multicolumn{2}{|c|}{ Experimental Group } & \multicolumn{2}{c|}{ Control Group } \\
\cline { 3 - 7 } & & $\mathbf{F}$ & $\mathbf{P ( \% )}$ & $\mathbf{F}$ & $\mathbf{P}(\mathbf{\%})$ \\
\hline 1 & Excellent & 95 to 100 & 0 & $0 \%$ & 0 & $0 \%$ \\
2 & Very Good & 85 to 94 & 0 & $0 \%$ & 0 & $0 \%$ \\
3 & Good & 75 to 84 & 1 & $3.3 \%$ & 0 & $0 \%$ \\
4 & Fairly Good & 65 to 74 & 0 & $0 \%$ & 0 & $0 \%$ \\
5 & Fair & 55 to 64 & 5 & $16.7 \%$ & 0 & $0 \%$ \\
6 & Poor & 45 to 54 & 4 & $13.3 \%$ & 4 & $13.3 \%$ \\
7 & Very Poor & 0 to 44 & 20 & $66.7 \%$ & 26 & $86.7 \%$ \\
\hline \multicolumn{2}{|l|}{ Total } & & 30 & $100 \%$ & 30 & $100 \%$ \\
\hline
\end{tabular}

The previous table shows that, the students' score of pre-test both of experimental and control group. It showed that, in experimental group 1 (3.3\%) student was good, 5 (16.7\%)students were fair, 4 (13.3\%)students were poor, and 20 $(66.7 \%)$ students were very poor.

In control group $4(13.3 \%)$ students were poor and 26 (86.7\%) students were very poor. The data proved that, the students' reading comprehension was still lack. 
Rini Anggraeni, The Effectiveness of Using Chunking Strategy To Improve Students' ...

Therefore, the researcher tried to apply chunking strategy in class to prove whether or not chunking strategy can improve and effective to use in teaching reading comprehension to overcome the students' problem in learning English especially reading comprehension.

After teaching reading comprehension using chunking strategy to an experimental group while the control group was taught without using chunking strategy both of them was given post-test for finding out whether there is an improvement after giving treatment or not. The score of students' post-test in both of group can be seen in the table below:

Table 4.2 The Data Percentage of Students' Score of Post-test

\begin{tabular}{|c|l|c|c|c|c|c|}
\hline \multirow{2}{*}{ No } & Classification & \multirow{2}{*}{ Score } & \multicolumn{2}{|c|}{ Experimental Group } & \multicolumn{2}{c|}{ Control Group } \\
\cline { 3 - 7 } & & & $\mathbf{F}$ & $\mathbf{P ( \% )}$ & $\mathbf{F}$ & $\mathbf{P ( \% )}$ \\
\hline 1 & Excellent & 95 to 100 & 0 & $0 \%$ & 0 & $0 \%$ \\
2 & Very Good & 85 to 94 & 0 & $0 \%$ & 0 & $0 \%$ \\
3 & Good & 75 to 84 & 2 & $6.66 \%$ & 0 & $0 \%$ \\
4 & Fairly Good & 65 to 74 & 6 & $20 \%$ & 0 & $0 \%$ \\
5 & Fair & 55 to 64 & 11 & $36.67 \%$ & 0 & $0 \%$ \\
6 & Poor & 45 to 54 & 8 & $26.67 \%$ & 0 & $0 \%$ \\
7 & Very Poor & 0 to 44 & 3 & $10 \%$ & 30 & $100 \%$ \\
\hline \multicolumn{2}{|c|}{ Total } & & 30 & $100 \%$ & 30 & $100 \%$ \\
\hline
\end{tabular}

The previous table shows that the students' post-test score both of experimental and control group. It showed that, in experimental group $6(20 \%)$ students were fairly good, 11 (36.67\%) students were fair, $8(26.67 \%)$ students were poor, $3(10 \%)$ students were very poor while in control group $30(100 \%)$ students were very poor. It means that, there was an improvement of students who was taught by using chunking strategy. It means that chunking strategy can help students to overcome their problem in comprehending the text while the students who were taught without using chunking strategy still lack in comprehending the reading text.

\section{b. The Mean Score and Standard Deviation of Students' in Experimental and Control Group}

After calculating the result of students' pre-test and post-test of experimental and control group by computer and formula the mean score and standard deviation can be presented in the table below: 
Table 4.3 Mean Score and Standard Deviation of Pre-test and Post-test

\begin{tabular}{|c|c|c|c|c|}
\hline \multirow{2}{*}{ Group } & \multicolumn{2}{|c|}{ Mean Score } & \multicolumn{2}{c|}{ Standard Deviation } \\
\cline { 2 - 5 } & Pre-test & Post-test & Pre-test & Post-test \\
\hline Experimental & 50 & 56 & 13,27 & 11,06 \\
\hline Control & 36 & 23 & 7,74 & 17,23 \\
\hline
\end{tabular}

The table 4.3 shows that, the mean score of the students' pre-test of experimental group were (50) and the mean score of students' post-test were (56). It is indicated that, the mean score of students' post-test was higher than the mean score of pre-test and the standard deviation of students' post-test of experimental group was lower than pre-test $(11,058<13,261)$. Thus, the researcher concluded that using chunking strategy can improve students' reading comprehension. However, the students' mean score of pre-test of control group was (36) higher than the mean score of students' post-test and the standard deviation of students' post-test was higher than pre-test. Therefore, without using chunking strategy there is no improvement of students' reading comprehension.

\section{c. The Result of Data Observation}

The following table showed the data observation of experimental group for the first meeting to the second meeting

\begin{tabular}{|c|l|c|c|c|c|c|}
\hline \multirow{2}{*}{ No } & \multicolumn{1}{|c|}{ Aspects } & \multirow{2}{*}{$\begin{array}{c}\text { Mean } \\
\text { Score }\end{array}$} & \multicolumn{2}{|c|}{ Meeting 1 } & \multicolumn{2}{|c|}{ Meeting 2 } \\
\cline { 4 - 8 } & & 70 & 20 & 66.7 & 22 & 73.3 \\
\hline 1 & $\begin{array}{l}\text { The students did assignment } \\
\text { based on the teachers' instruction. }\end{array}$ & & & & F & P (\%) \\
\hline 2 & $\begin{array}{l}\text { The students asked question to } \\
\text { their teacher if there is an } \\
\text { instruction which is not clear. }\end{array}$ & 71.65 & 21 & 70 & 22 & 73.3 \\
\hline 3 & $\begin{array}{l}\text { The students gave commend and } \\
\text { suggestion about their friends' job. }\end{array}$ & 76.7 & 23 & 76.7 & 23 & 76.7 \\
\hline 4 & $\begin{array}{l}\text { The students presented their } \\
\text { discussion result without } \\
\text { appointed by the teacher. }\end{array}$ & 68.35 & 20 & 66.7 & 21 & 70 \\
\hline 5 & $\begin{array}{l}\text { The students discussed and } \\
\text { worked together with their friends } \\
\text { in doing their assignments. }\end{array}$ & 75 & 22 & 73.3 & 23 & 76.7 \\
\hline
\end{tabular}


Rini Anggraeni, The Effectiveness of Using Chunking Strategy To Improve Students' ...

\begin{tabular}{|c|l|c|c|c|c|c|}
\hline 6 & $\begin{array}{l}\text { The students did assignments } \\
\text { from their teacher well. }\end{array}$ & 70 & 20 & 66.7 & 22 & 73.3 \\
\hline 7 & $\begin{array}{l}\text { The students always showed their } \\
\text { curiosities with asking question to } \\
\text { their teacher and friends. }\end{array}$ & 58.35 & 15 & 50 & 20 & 66.7 \\
\hline 8 & The students explored their ideas. & 65 & 19 & 63.3 & 20 & 66.7 \\
\hline 9 & $\begin{array}{l}\text { The students thought and were } \\
\text { not hopeless for looking for } \\
\text { answer using book or asking their } \\
\text { friends }\end{array}$ & 76.65 & 22 & 73.3 & 24 & 80 \\
\hline 10 & $\begin{array}{l}\text { The students looked happy in } \\
\text { learning process }\end{array}$ & 86.65 & 25 & 83.3 & 27 & 90 \\
\hline 11 & $\begin{array}{l}\text { The students were not sleepy } \\
\text { during the teaching and learning } \\
\text { process. }\end{array}$ & 78.3 & 22 & 73.3 & 25 & 83.3 \\
\hline 12 & $\begin{array}{l}\text { The students discussed with their } \\
\text { teacher. }\end{array}$ & 78.35 & 23 & 76.7 & 24 & 80 \\
\hline 13 & $\begin{array}{l}\text { The students discussed with their } \\
\text { friends. }\end{array}$ & 80 & 23 & 76.7 & 25 & 83.3 \\
\hline 14 & $\begin{array}{l}\text { The students worked together } \\
\text { with their partner. }\end{array}$ & 83.3 & 24 & 80 & 26 & 86.6 \\
\hline
\end{tabular}

Based on the previous table showed that there an improvement of students from the first meeting to the second meeting, the researcher found that there were 22 of 30 students did assignment based on the teachers' instruction,22 of 30 students asked question to their teacher if there is an instruction which is not clear, 23 of 30 students gave commend and suggestion about their friends' job, 21 of 30 students presented their discussion result without appointed by the teachers, 23 of 30 students discussed and worked together with their friends in doing their assignments, 22 of 30 students did assignments from their teacher well, 20 of 30 students always showed their curiosities with asking question to their teacher and friends, 20 of 30 students explored their ideas, 24 of 30 students thought and were not hopeless for looking for answer using book or asking their friends, 27 of 30 students looked happy in learning process, 25 of 30 students were not sleepy during the teaching and learning process, 24 of 30 students discussed with their teacher, 25 of 30 students discussed with their friends, 26 of 30 students worked together with their partner. 


\section{F. CONCLUSION}

The results of this study showed that the use of chunking strategy was effective to use in learning process to teach reading comprehension. It could be seen from the improvement of students' score of pre-test and post-test had improved. Furthermore, relating to the research findings, the conclusion are presented as follows: 1). Chunking strategy was effective and good strategy to use in teaching reading comprehension because this strategy help students understand and remember the information easily; 2). Utilizing chunking strategy could improve the students' achievement and could overcome the students' problem (lack of vocabulary and misunderstanding of words); 3). Chunking Strategy could encourage the students' motivation and involvement in the class; 4). Achievement was influence by students' attitude. Having good attitude will get a good achievement. Therefore, students should maintain their attitude for getting a good achievement during learning process.

\section{G. RECOMMENDATION}

Since this study has been successful to improve students reading comprehension, it is suggested that the English teachers can apply this strategy based on the students' needed and problem to improve students' reading comprehension. The researcher also suggests that the teachers have to explain the advantages of using chunking strategy in reading course to the students so that they can realize what they are doing is very useful. Then, the researcher suggests that the teacher should make those activities as creative as possible because all of the good strategy should be designed as good as possible to attract the students' interest.

\section{REFERENCES}

Adlit. Inferential reading. Online. Retrieved on January $13^{\text {rd }}$ 2015at http://www.adlit.org/strategies/23355/.2015.

Asmawati.The Use of "Super Six" Comprehension Strategies to Increase the Students' Reading Comprehension at the Tenth Grade Students of SMA Gunung Sari Makassar. Thesis of Bachelor Degree, Faculty of Tarbiyah and Teaching Science, UIN Alauddin Makassar, Makssar. 2012.

Aiken, L. S. Psychology Testing and Assessment. $4^{\text {th }}$ ed. Bostom: Allyn and Bacon. 1982.

Amalia, Indah. Improving Students' Reading Comprehension by Using Retelling Joke Story Method of the First Year students of SMAN 3 Sinjai. Thesis of Bachelor Degree, 
Rini Anggraeni, The Effectiveness of Using Chunking Strategy To Improve Students' ...

Faculty of Tarbiyah and Teaching Science, UIN Alauddin Makassar, Makassar. 2014.

Ardhana, W. MetodeStatistikUntukPenelitianPendidikan. Surabaya: Usaha Nasional. 1982.

Arikunto, S. ProsedurPenelitianSuatuPendekatanPraktek. Jakarta: PT RinekaCipta. 2013.

Balsiger, Linda. Reading Comprehension- Reading but Not Understanding. www.Bendlanguagelearning.com. Accessed on Tuesday 04 ${ }^{\text {th }}$ March 2015.

Bondaza, A., Kelly, K, \&Treewater, A. Means of Improving Reading Comprehension. (Available through E-Subscribe).1998.

Brown, H. Douglas. Teaching by Principles. San Francisco: Addison Wesley Longman, Inc. 2001.

Cahyono, BambangYudi and ShirlyRizkiKusumaningrum. Practical Techniques for English Language Teaching. Malang: State University of Malang Press. 2011.

Cahyono, BambangYudi. The Teaching of English Language Skills and English Language Componets. Malang: State University of Malang Press. 2010.

Casteel, C. Effects of chunked reading among learning disabled students: An experimental comparison of computer and traditional chunked passages. Online. Retrieved on July 17, 2012 at http://www.cehd.umn.edu/nceo/presentations/NCEO-LEPIEP-ASCDHandoutChunking.pdf. 1998.

Casteel, C. Effects of Chunked Text-Material on Reading Comprehension of High and Low Ability Readers. Online. Retrieved on January 13rd, 2015 at http://www.cehd.umn.edu/nceo/presentations/NCEO-LEP-IEPASCDHandoutChunking.pdf. 1989.

Cooper, J. D. Improving Reading Comprehension. Boston: Houghtonmiffin Company. 1986.

Gay, L.R. Educational Research: Competencies for Analysis and Application (2 ${ }^{\text {nd }}$ ed). USA: Charles E. Merril Publishing Co, 1981.

Gay, L.R.Educational Research: Competencies for Analysis and Application, $3^{\text {rd }}$ ed. Singapore: Macmillan Publishing Company. 1990.

Grabe, William and Stoller, Fedricka L. Teaching and Researching Reading. Great Britain: Pearson Education. 2012.

Hamid, Abdul Waris. Teaching Reading Comprehension and Extensive Reading. Makassar: Alauddin University Press. 2011.

Harmer, Jerremy. The Practice of English Language Teaching. New York: Longman, Inc.

Harris, Albertr, J. How to Increase Reading Ability. New York: Longman, Inc. 1980. 
Hills, Cherry. Chunking. Online. Retrieved on Monday, $13^{\text {th }}$ January 2015 at http://www.skillstoolbox.com/career-and-education-skills/learningskills/effective-learning-strategies/chunking/. 2015.

Irmayani. The Effectiveness of Using Question-Answer-Relation (QAR) Strategy in Improving the Students' Reading Comprehension at the Eight Grade Students at SMP Negeri 25 Bulukumba. Thesis of Bachelor Degree, Faculty of Tarbiyah and Teaching Science, UIN AlauddinMakassar, Makassar. 2012.

Kahayanto, E. A Comparative Study on Students' Achievement in Reading of the Education Study Program of Palangka Raya University who Entered Through PSB and SPMB in Academic Year 2003/2004. Unpublished Thesis. Palangka Raya: The Faculty of Teacher Training and Education University of Palangka Raya. 2005.

Kasmawati. The improvement of the students' literal comprehension through Carousel Brainstorm Strategy at the Second Grade Students' of MTs. Mubammadiyah Tallo. Thesis of Bachelor Degree, Faculty of Muhammadiyah Makassar, Makassar. 2009.

Keenan, S. Effects of chunking and line length on reading efficiency. 1984.

Khalikin. Developing Reading Skills: A Practical Guide to Reading Comprehension Exercises. Cambridge: Cambridge University Press. 2011.

Lauren, Ashley. Comprehension Activities for Chunking. Online. Retrieved on January, $12^{\text {th }} 2015$ at http://www.ehow.com/info 8705350 comprehensionactivities-chunking.html.2015.

Malamed, Connie. Chunking Information for Instructional Design. Online. Retrieved on January, $12^{\text {th }} 2015$ at http://theelearningcoach.com/elearning design/ chunking-information/.2015.

Marhamah. Improving Students' Reading Comprehension by Using Group Investigation (GI) Method at The Second Year of MTS. AisyiahSungguminasa. Thesis of bachelor Degree, faculty of Tarbiyah and teaching Science, UIN Alauddin Makassar, Makassar. 2013

Miller, G. The magical number seven, plus or minus two: Some limits on our capacity for processing information. Journal. Psychological Review, 101, (2), 343-352. 1956.

Mirawati. Using Context Clues to Improve the Students' reading Comprehension at SMA Negeri 1 Mangarombang. Thesis of Bachelor Degree, Faculty of Tarbiyah and Teaching Science, UIN Alauddin Makassar, Makassar. 2011.

Nunan, David. Language Teaching Methodology. New York: Pretince hall. 1991.

Nursiah. The Students' achievement in Reading Narrative Text of the Second Year of SMAN 1 MaiwaEnrekangThrough Student Teams Achievement Division (STAD) method. Thesis of Bachelor Degree, Faculty of Tarbiyah and Teaching Science, UIN Alauddin Makassar, Makassar. 2012. 
Rini Anggraeni, The Effectiveness of Using Chunking Strategy To Improve Students' ...

Nuttal, C. Teaching Reading Skill in a Foreign Language. Landon: Heinemann Education Books. 1982.

Schreiber, James B and Asner- Self K. Educational Research: The Interellationship of Questions, Sampling, Design, and Analysis. United States: John Wiley \& Sons, Inc, 2011.

Setiyadi, Bambang. Metode Penelitian Pengajaran Bahasa Asing. Yogyakarta: Penerbit GrahaIlmu. 2006.

Shoop, M. Reading aloud to students: Questioning strategies to listening comprehension. 1987.

Singer. Theoretical Models and Process of Reading. Barkeley: University of California. 1985.

Smith, Richard J. and Dale D. Johnson. Teaching Children to Read. Second Edition. USA: Addison-Wesley Publishing Company.1980.

Sugiyono. MetodePenelitianPendidikan (PendekatanKuantitatif, Kualitatif, dan R\&D). Bandung: Alfabeta. 2013

Richards, Jacket. Longman Dictionary of Applied Linguistics, Longman House: England. 1995.

Tomlinson, Brian. (Ed). Developing Material for Language Teaching. New York: Continuum. 2003.

Waris, A. H. Teaching Reading Comprehension and Extensive Reading. Makassar: Alauddin University Press. 2011.

Wise, R. Reading Comprehension Strategies: How to Use Chunking, Monitoring, \& Listening. Online. Retrieved on January 13, from file:///C:/Users/Intel\%20Corporate/ Documents $/$ Reading $\% 20$ Comprehension $\% 20$ Strategies $\% 20$ for $\% 20$ Kids.htm 1. 2015. 